UDC 678.5

\author{
A.Yu. Poloz ${ }^{a}$, N.R. Prokopchuk ${ }^{b}$, R.M. Dolinskaya ${ }^{b}$, Yu.R. Ebich ${ }^{c}$
}

\title{
THE INFLUENCE OF POLYAMINES ON THE PROPERTIES OF EPOXY COMPOSITES
}

\author{
a LTD «New Technologies», Dnipro, Ukraine \\ ${ }^{b}$ Belarusian State Technological University, Minsk, Belarus \\ ${ }^{c}$ Ukrainian State University of Chemical Technology, Dnipro, Ukraine
}

\begin{abstract}
The viscoelastic properties of epoxy resin-based composites ED-20 in a mixture with aliphatic epoxy resin DEG-1 have been determined as functions of the applied industrial polyamine hardener and additional heat treatment (at the temperatures of $60-140^{\circ} \mathrm{C}$ ). The differences in the thermomechanical and physical-mechanical properties, and wear resistance of the composites have been stated resulted from the change in the ratio of the energies of elastic and viscous deformation. The ratio of the energies of elastic and viscous deformation of composites in a dynamic loading mode is influenced by the formed spatial cross-linked structure of the epoxy matrix. The effects of the temperature of additional heat treatment on the change in thermomechanical properties and the nature of the destruction of epoxy composites have been shown. It has been proposed to apply a combined heat treatment conditions $\left(80+100^{\circ} \mathrm{C}\right)$. To achieve optimum viscoelastic properties after hardening at $20^{\circ} \mathrm{C}$, it is expedient to heat-treat the obtained epoxy composites in a vitreous state at temperatures close to vitrification temperature and use a Polyamine B hardener.
\end{abstract}

Keywords: epoxy resin, polyamine hardener, cross-linked structure, viscoelastic properties, wear resistance.

DOI: $10.32434 / 0321-4095-2019-126-5-118-125$

\section{Introduction}

Epoxy composites possess a number of important operational properties such as high durability, adhesion to various types of substrata, wear resistance, resistance to various media $[1,2]$. They are widely used in the production and repair of parts that are operated under the conditions of the intensive impact of abrasive media [3-5]. For such composites, epoxy resins are most commonly used with aliphatic epoxy-containing diluents, which are applied to reduce their viscosity and participate in the formation of mixed network structures. The curing of these compositions is carried out with polyamines using energy-saving technology at the temperature of $20^{\circ} \mathrm{C}$, followed by further curing at $80-120^{\circ} \mathrm{C}$ [6]. The kinetic features of the curing of mixtures of dianic and aliphatic epoxy resins with aliphatic polyamines have been discussed elsewhere [7]. At the same time, the conditions of timetemperature curing, the chemical nature and concentration of polyamine hardeners that affect the exothermic reaction of the interaction of epoxy resin groups with amine hardening groups, wear resistance under conditions of contact dynamic loading [8], viscoelastic and other operational properties of composites were to a considerable degree overlooked. However, these data are necessary to correctly select appropriate polyamine hardeners in fabricating the required technological and operational properties, taking into account the expansion of the market of the used hardeners.

Therefore, the objective of this study was to determine the most important operational properties of epoxy composites under static and dynamic conditions in order to promote understanding of the mechanism for ensuring the working capacity of composite materials under critical conditions. The main attention was paid to the role of the ratio of elastic and viscous characteristics of epoxy composites in ensuring their operational properties.

\section{Experimental}

Epoxy-diane resin ED-20 was used as an epoxy matrix $\left(M_{n}=390 \mathrm{~g} / \mathrm{mol}\right.$, the content of epoxy groups was 21.8 wt.\%), whereas diglycidyl ether of diethylene

(C) A.Yu. Poloz, N.R. Prokopchuk, R.M. Dolinskaya, Yu.R. Ebich, 2019 
glycol DEG-1 (the content of epoxy groups was $25.7 \mathrm{wt} . \%$, dynamic viscosity was equal to $0.07 \mathrm{~Pa} \cdot \mathrm{s}$ at $\left.25^{\circ} \mathrm{C}\right)$ was used as an active thinner $(10 \mathrm{wt} .-100 \mathrm{wt}$., resin). The low-viscosity light liquids that were used as polyamine hardeners met the standards of producing companies. The hardeners were added in the quantities recommended by manufacturers and had the following characteristics: polyethylene polyamine is a mixture of linear and branched ethylene and piperazine containing ethylene polyamines from diethylentriamin and $\mathrm{N}$-aminoethylpiperazine to compounds with 6-7 nitrogen atoms, dynamic viscosity $(\eta)$ equals $90 \mathrm{mPa} \cdot \mathrm{s}$ at $25^{\circ} \mathrm{C}$, amine number (A) is equal to $205 \mathrm{mg} \mathrm{KOH} / \mathrm{g}$; Polyamine $\mathrm{B}$ is a mixture of a tetraethylenpentamin, pentaethylenegexamine, hexaethylenheptamine and amines with higher molecular weight, the content of a tetraethylenepentamine (TERA) is $15 \mathrm{wt} . \%$, the content of amines with higher boiling point than the boiling point of pentamines is $83 \mathrm{wt} . \%$, the content of amines with lower boiling point is equal to $1 \mathrm{wt} . \%$; Ancamine 2692 is the modified cycloaliphatic polyamine, $\eta=120 \mathrm{mPa} \cdot \mathrm{s}, \mathrm{A}=300 \mathrm{mg} \mathrm{KOH} / \mathrm{g}$; Ancamine 2686 is the modified cycloaliphatic polyamine, $\eta=135 \mathrm{mPa} \cdot \mathrm{s}, \mathrm{A}=310 \mathrm{mg} \mathrm{KOH} / \mathrm{g}$; Ancamine 2752 is the modified cycloaliphatic polyamine, $\eta=390 \mathrm{mPa} \cdot \mathrm{s}$, hydrogen equivalent $(\mathrm{H})$ of $95 \mathrm{~g} / \mathrm{eq}$; Ancamine 1638 is the modified aliphatic polyamine, $\eta=100 \mathrm{mPa} \cdot \mathrm{s}, \mathrm{A}=1070 \mathrm{mg} \mathrm{KOH} / \mathrm{g}, \mathrm{H}=$ $=31 \mathrm{~g} / \mathrm{eq} ; \mathrm{CeTePox} 1410 \mathrm{H}$ is the modified cycloaliphatic polyamine, $\eta=550 \mathrm{mPa} \cdot \mathrm{s}, \mathrm{H}=95 \mathrm{~g} / \mathrm{eq}$; and Epikure F-205 is the modified cycloaliphatic polyamine, $\eta=500 \mathrm{mPa} \cdot \mathrm{s}, \mathrm{H}=105 \mathrm{~g} / \mathrm{eq}$.

Compositions were prepared by introducing epoxy-diane resin ED-20 and active thinner into the reactor of periodic action at the temperature of $60^{\circ} \mathrm{C}$, the components were mixed for 15 minutes. Polyamine hardeners were previously added to compositions at the temperature of $20-25^{\circ} \mathrm{C}$ and mixed for 5-7 minutes. The prepared compositions were poured into the relevant molds and cooled with the use of energy-saving procedure at $20 \pm 2^{\circ} \mathrm{C}$ during 24 hours. The samples were subjected to the heat treatment at $60-140^{\circ} \mathrm{C}$ for 3 hours, and they were also heat-treated under the optimized conditions at $80+100^{\circ} \mathrm{C}$ in order to improve the properties of composites.

The exothermic reaction of hardening was studied with the constant amount of resin $(50 \mathrm{~g})$ in compositions using thermocomplex supplied with the thermocouple and the display with temperature readings in the center of composition volume [9].

The temperature readings were taken every 2 minutes, fixing the maximum temperature of the reaction and its reduction. When processing the data of temperature change of the exothermic reaction of hardening, the onset of gelation was found by extrapolation a tangent to the experimental curve of rise in temperature of composition in the main period to the axis of abscissas.

The rate of temperature change in the main period of the hardening reaction (at a sharp rise in temperature, ${ }^{0} \mathrm{C} / \mathrm{min}$ ) was determined from the tangent of the angle of inclination of the tangential temperature change from the gel point to the point with the maximum temperature taking into account the duration of this period [9].

The course of hardening reaction and formation of the cross-linked structure of composites were characterized by the contents of sol-fraction (S), cross-linked coefficient $(\gamma)$, the average molecular mass of interstitial chains $\left(M_{c}\right)$, and the cells size formed by interstitial chains of polymers according to the X-ray diffraction analysis.

The content of sol fraction in the samples was determined from the change in their mass after extraction with acetone during boiling in a Sokslet's device for 6 hours. The cross-linked coefficient, $\gamma$, was calculated with the use of the following formula [10]:

$$
\gamma=\frac{1 / S^{0.5}-1}{1-S}
$$

The average molecular mass of interstitial chains $\left(\mathrm{M}_{\mathrm{c}}, \mathrm{g} / \mathrm{mol}\right)$ and the equilibrium modulus of highelasticity $\left(\mathrm{E}_{\mathrm{e}}, \mathrm{MPa}\right)$ were calculated on the basis of the thermomechanical measurements according to the following equations $[11,12]$ :

$$
\mathrm{M}_{\mathrm{c}}=\frac{3 \rho \mathrm{RT}_{\mathrm{e}}}{\mathrm{E}_{\mathrm{e}}} ; \mathrm{E}_{\mathrm{e}}=\frac{\mathrm{F}}{\mathrm{S}} \cdot \frac{\mathrm{h}}{\Delta \mathrm{h}},
$$

where $\mathrm{F}$ is the permanent load of a sample, $\mathrm{H} ; \mathrm{S}$ is the cross-sectional area of a sample; $h_{0}$ is the initial height of a sample, $\mathrm{mm} ; \Delta \mathrm{h}$ is the deformation of a sample upon reaching a highly elastic state, $\mathrm{mm} ; \rho$ is the polymer density, $\mathrm{g} / \mathrm{cmi} ; \mathrm{R}$ is the universal gas constant $(\mathrm{R}=83,14 \mathrm{kgf} \cdot \mathrm{cm} / \mathrm{mol} \cdot \mathrm{K}) ; \mathrm{T}_{\mathrm{e}}$ is the temperature of transition to a highly elastic state, $\mathrm{K}$; and $E_{e}$ is the equilibrium module of high-elasticity, MPa.

The temperatures of glass transition, $T_{g}$, and transition to the highly elastic state, $T_{e}$, of the cured samples were also determined by the thermomechanical method. The measurements were performed using cylindrical samples $(10 \mathrm{~mm}$ in diameter and height) with permanent unit load equal to $0.75 \mathrm{MPa}$, 
the heating rate was $4^{0} \mathrm{C} / \mathrm{min}$.

The X-ray diffraction analysis of the composites was conducted by using methods of wide-angle and small-angle scattering of X-rays. Wide-angle X-ray scattering was carried out using the $X$-ray diffractometer with the slit-type collimation of Xrays primary beam and the X-ray optical scheme based on primary beam «passing» through the sample.

Small-angle X-ray scattering was carried out using the small-angle X-ray camera equipped with the Kratky-type slit collimator. The geometric parameters of the camera satisfied the condition of infinite height of the primary beam [13].

$\mathrm{X}$-ray diffraction study was performed at the temperature of $22^{\circ} \mathrm{C}$ in $\mathrm{CuK}_{\alpha}$ radiation (wavelength $\lambda=0.154 \mathrm{~nm}$ ), monochromated with a Ni filter.

Because of extension of the epoxy composites' scope of application, their properties were defined under the static and dynamic conditions. The main physical-mechanical properties were determined under the static conditions on flat samples $15 \mathrm{~mm}$ width, $10 \mathrm{~mm}$ thick and $125 \mathrm{~mm}$ length according to the accepted standards. The samples were viscoelastic at the temperature of $22 \pm 2^{\circ} \mathrm{C}$ under the dynamic conditions; IPM-1K device was used [14] according to the relevant mathematical dependences. The device uses a dynamic indentation method, which consists in striking by means of a rigid indenter on the tested composite in a single pulse mode [14]. Under impulsive loading, the composite shows viscoelastic properties that cannot be estimated in case of static influence; in addition, dynamic loading simulates the most stringent conditions that a composite material can undergo during operation. Viscoelastic properties were characterized with the use of the models of Maxwell and Kelvin-Voigt. The Maxwell model describes the stress relaxation of a solid to a first approximation, and the Kelvin-Voigt model describes its creep [15].

The wear resistance of the composites was estimated under the conditions of rigid gas-abrasive wear of samples $(20 \times 15 \times 4 \mathrm{~mm})$ by a sand particle flow of $0.5-0.9 \mathrm{~mm}$ at a speed of $76 \mathrm{~m} / \mathrm{s}$ on a centrifugal solid particle accelerator at different abrasive attack angles: $15^{\circ}, 30^{\circ}, 45^{\circ}, 60^{\circ}$ and $90^{\circ}$.

\section{Results and discussion}

Polyamines are widely used as hardeners for cold-cured epoxy composites, in particular polyethylene polyamine (PEPA), in amounts close to stoichiometric ones (9-12 wt. per 100 wt. ED-20). The concentration of the hardener determines the spatial cross-linked structure of the composites and, therefore, their viscoelastic properties, wear resistance and other characteristics.
According to Fig. 1, the unfilled epoxy composites obtained using 10-12 wt. of PEPA possess optimum viscoelastic properties and shows the minimum values of mechanical loss angle tangent.

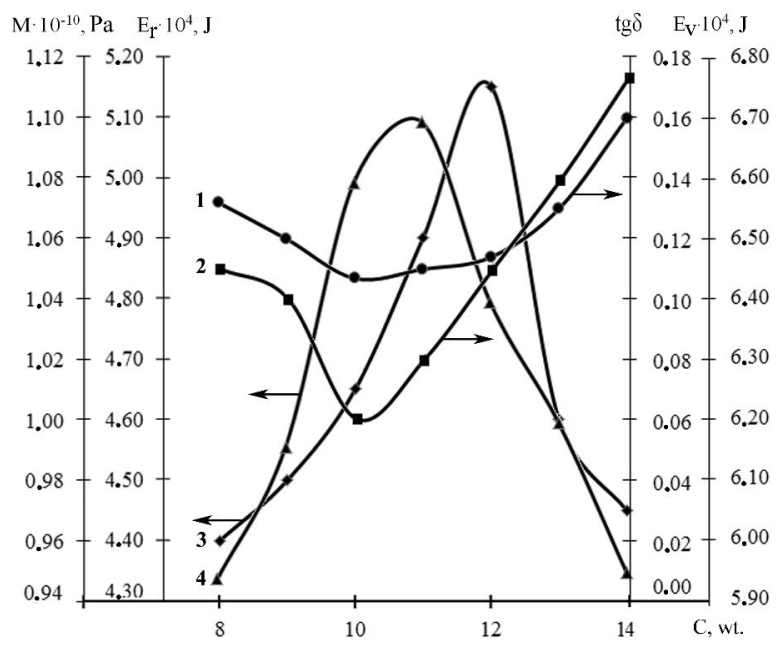

Fig. 1. The effect of polyethylene polyamine concentration (C) on the properties of ED-20 epoxy-based composites:

1 - mechanical loss angle tangent, tgd; 2 - energy of viscous deformation $\mathrm{E}_{\mathrm{v}} ; 3$ - modulus of elasticity $\mathrm{M}$; and 4 - energy of resilient deformation $E_{r}$

Excess hardener (14 wt.) is a plasticizer which decreases the dynamic module of elasticity, deformation energy and increases the energy of viscous deformation.

Wear resistance of composites corresponds to the values of the deformation energy and its component, the energy of elastic deformation.

Polyamine hardeners of various manufacturers have different impacts on the course of the exothermic reaction of hardening during the interaction of epoxy resin groups with amine groups of polyamines.

The developed temperature during this reaction influences a number of important technological parameters (the «viability» time associated with the course of jellification process, the rate of temperature increase during hardening, etc.) and the operational properties related to the uneven distribution of the created three-dimensional grid with the rapid increase in the high temperature of reaction.

As shown in Table 1, the maximum temperature of an exothermic reaction and maximum temperature change rate in the main period are observed for Ancamine hardeners; the lowest temperature of exothermic reaction of hardening is achieved when 
Table 1

The effect of industrial polyamines on the process of epoxy compositions hardening and their properties (hardening conditions: $\left.20^{\circ} \mathrm{C} \times 24 \mathrm{~h}+100^{\circ} \mathrm{C} \times 3 \mathrm{~h}\right)$

\begin{tabular}{|c|c|c|c|c|c|c|c|c|}
\hline \multirow[b]{2}{*}{ Indicators } & \multicolumn{8}{|c|}{ Polyamines } \\
\hline & 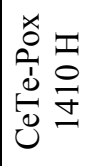 & 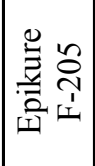 & 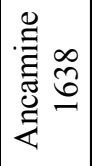 & : & 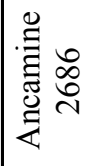 & 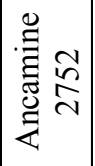 & 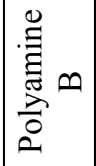 & $\frac{\overleftarrow{a}}{\frac{\mathbb{I}}{a}}$ \\
\hline Concentration of a hardener, wt. & 54 & 58 & 15 & 50 & 50 & 50 & 10 & 10 \\
\hline \multirow{3}{*}{$\begin{array}{l}\text { Parameters of exothermic reaction of hardening: } \\
\text { maximum temperature, }{ }^{0} \mathrm{C} \\
\text { time of the beginning of jellification, min } \\
\text { rate of change of temperature in the main period, }{ }^{0} \mathrm{C} / \mathrm{min}\end{array}$} & 118 & 120 & 156 & 134 & 138 & 133 & 98 & 124 \\
\hline & 22 & 22 & 16 & 34 & 32 & 34 & 29 & 32 \\
\hline & 9.13 & 4.00 & 28.50 & 10.20 & 11.70 & 10.13 & 4.37 & 3.67 \\
\hline \multirow{2}{*}{$\begin{array}{l}\text { Parameters of three-dimensional structure: } \\
\text { maintenance of zol-fractions S, wt.\% } \\
\text { cross-linked coefficient } \gamma\end{array}$} & 0.18 & 0.17 & 0.33 & 0.33 & 0.31 & 0.38 & 0.24 & 0.28 \\
\hline & 22.9 & 23.5 & 16.4 & 16.4 & 16.9 & 15.2 & 19.4 & 17.9 \\
\hline \multirow{5}{*}{$\begin{array}{l}\text { Physical-mechanical properties: } \\
\text { impact strength determined according } \\
\mathrm{kJ} / \mathrm{m}^{2} \\
\text { flexural strength, } \mathrm{MPa} \\
\text { tensile strength, } \mathrm{MPa} \\
\text { relative deformation at stretching, \% } \\
\text { compressive strength, } \mathrm{MPa} \\
\end{array}$} & 15.0 & 16.5 & 10.0 & 9,7 & 10.5 & 9.2 & 14.8 & 14.3 \\
\hline & 87 & 84 & 95 & 98 & 96 & 110 & 91 & 92 \\
\hline & 30.0 & 30.8 & 35.4 & 36.1 & 36.7 & 37.6 & 28.1 & 22.3 \\
\hline & \begin{tabular}{|l|}
13.0 \\
\end{tabular} & 12.7 & 15.0 & 15.0 & 15.5 & 16.0 & 13.5 & 13.6 \\
\hline & 146 & 138 & 155 & 155 & 157 & 150 & 160 & 156 \\
\hline \multirow{7}{*}{$\begin{array}{l}\text { Viscoelastic properties at dynamic loading: } \\
\text { modulus of elasticity } \mathrm{M} \cdot 10^{-10}, \mathrm{~Pa} \\
\text { mechanical loss angle tangent, tg } \delta \\
\text { energy of deformation } \mathrm{E}_{\mathrm{d}} \cdot 10^{3}, \mathrm{~J} \\
\text { energy of elastic deformation, } \mathrm{E}_{\mathrm{e}} \cdot 10^{4}, \mathrm{~J} \\
\text { energy of viscous deformation, } \mathrm{E}_{\mathrm{v}} \cdot 10^{4}, \mathrm{~J} \\
\text { viscosity determined according to the Kelvin-Voigt model, N·s } \\
\text { viscosity determined according to the Maxwell model, } \mathrm{N} \cdot \mathrm{s} \\
\end{array}$} & 1.36 & 1.43 & 1.30 & 1.29 & 1.31 & 1.27 & 1.33 & 1.32 \\
\hline & \begin{tabular}{|l|}
0.097 \\
\end{tabular} & 0.093 & 0.114 & 0.111 & 0.113 & 0.110 & 0.108 & 0.109 \\
\hline & 1.097 & 1.114 & 1.060 & 1.059 & 1.064 & 1.031 & 1.085 & 1.072 \\
\hline & \begin{tabular}{|l|}
5.811 \\
\end{tabular} & 6.656 & \begin{tabular}{|l|}
5.210 \\
\end{tabular} & 5.201 & 5.266 & 4.916 & 5.563 & 5.375 \\
\hline & \begin{tabular}{|l}
5.159 \\
\end{tabular} & 4.484 & 5.390 & 5.389 & 5.374 & 5.394 & 5.287 & 5.345 \\
\hline & 6.53 & 6.63 & 6.30 & 6.27 & 6.37 & 6.09 & 6.46 & 6.42 \\
\hline & 665 & 765 & 465 & 444 & 524 & 444 & 549 & 530 \\
\hline \multirow{5}{*}{$\begin{array}{r}\text { Deterioration }\left(\Delta \mathrm{V} \cdot 10^{3}, \mathrm{c}\right. \\
\text { of attack equal to: } 15^{0} \\
30^{\circ} \\
45^{0} \\
60^{0} \\
90^{\circ}\end{array}$} & 5.4 & 2.4 & 9.0 & 9.4 & 7.5 & 13.7 & 6.6 & 7.0 \\
\hline & \begin{tabular}{|l|}
12.7 \\
\end{tabular} & 10.7 & 20.9 & 22.8 & 16.1 & 28.5 & 14.7 & 15.4 \\
\hline & \begin{tabular}{|l|}
14.7 \\
\end{tabular} & 15.9 & \begin{tabular}{|l|}
22.2 \\
\end{tabular} & 24.1 & 18.4 & 30.5 & 17.2 & \begin{tabular}{|l|}
17.8 \\
\end{tabular} \\
\hline & 8.5 & 6.6 & \begin{tabular}{|l|}
13.4 \\
\end{tabular} & 14.0 & 12.5 & 17.6 & 10.8 & \begin{tabular}{|l|}
11.9 \\
\end{tabular} \\
\hline & 2.4 & 1.0 & 8.0 & 8.3 & 7.0 & 12.5 & 5.7 & 6.1 \\
\hline
\end{tabular}

using a hardener of Polyamine B.

High temperature of the exothermic hardening reaction and the rate of its change in the main period as well as the heat release rate during this process result in an uneven course of the process of threedimensional grid formation and an increase in the proportion of resin macromolecules in the grid.

Indeed, the deepest course of the hardening process according to the sol-gel analysis (Table 1) and the maximum degree of cross-linking of the epoxy composites are observed when using Epikure F-205, CeTePox $1410 \mathrm{H}$ and Polyamine B hardeners, which provide more favorable hardening conditions at a lower temperature rise rate in the main period. Rather high rate of change in the temperature of the exothermic hardening reaction in the presence of Ancamine hardeners leads to a smaller degree of completeness of the process, which is reflected in wear resistance under the conditions of intensive gasabrasive wear of composites, their physicalmechanical and viscoelastic properties.

It is known [7] that the use of dynamic methods of mesh polymers research allows characterizing the degree of functional groups transformation and the density of cross-links in mesh polymer by the modulus of elasticity. Table 1 shows that there is a strong correlation between the dynamic modulus of elasticity and cross-linking coefficient of epoxy composites.

Other viscoelastic properties of epoxy 
Table 2

The effect of the additional heat treatment temperature on the properties of unfilled epoxy composites (the duration of heat treatment is 3 hours after the main hardening according to the $20^{\circ} \mathrm{C} \times 24 \mathrm{~h}$ mode; the PEPA hardener)

\begin{tabular}{|c|c|c|c|c|c|c|c|}
\hline \multirow[b]{2}{*}{ Indicators } & \multicolumn{7}{|c|}{ Heat treatment temperature, ${ }^{0} \mathrm{C}$} \\
\hline & $\begin{array}{c}\text { without heat } \\
\text { treatment }\end{array}$ & 60 & 80 & 100 & 120 & 140 & $80+100$ \\
\hline \multirow{3}{*}{$\begin{array}{l}\text { Parameters of three-dimensional structure: } \\
\text { maintenance of zol-fraction } \mathrm{S}, \text { wt. } \% \\
\text { cross-linked coefficient } \gamma \\
\text { average molecular mass of interstitial chains of } \mathrm{M}_{\mathrm{c}}, \mathrm{g} / \mathrm{mol}\end{array}$} & 13.96 & 3.58 & 3.07 & 2.18 & 2.45 & 3.74 & 0.32 \\
\hline & 1.95 & 4.44 & 4.86 & 5.90 & 5.53 & \begin{tabular}{|l|l|}
4.33 \\
\end{tabular} & 73 \\
\hline & 6519 & 4795 & 2612 & 1370 & 1586 & 2733 & 32 \\
\hline \multirow{3}{*}{$\begin{array}{l}\text { Glass transition temperature } \mathrm{T}_{\mathrm{g}},{ }^{0} \mathrm{C} \\
\text { Temperature of transition to a highly elastic state } \mathrm{T}_{\mathrm{e}},{ }^{0} \mathrm{C} \\
\text { High-elasticity modulus } \mathrm{E}_{\mathrm{e}}, \mathrm{MPa}\end{array}$} & 70 & 73 & 95 & 115 & 114 & 93 & 118 \\
\hline & 77 & 84 & \begin{tabular}{|l|l|}
108 \\
\end{tabular} & 129 & 127 & 105 & 132 \\
\hline & 1.76 & 2.45 & \begin{tabular}{|l}
4.89 \\
\end{tabular} & 9.91 & \begin{tabular}{|l}
8.49 \\
\end{tabular} & 4.62 & 14.68 \\
\hline \multirow{7}{*}{$\begin{array}{l}\text { Viscoelastic properties at dynamic loading: } \\
\text { modulus of elasticity } \mathrm{M} \cdot 10^{-10}, \mathrm{~Pa} \\
\text { mechanical loss angle tangent, } \operatorname{tg} \delta \\
\text { energy of deformation } \mathrm{E}_{\mathrm{d}} \cdot 10^{3}, \mathrm{~J} \\
\text { energy of elastic deformation, } \mathrm{E}_{\mathrm{e}} \cdot 10^{4}, \mathrm{~J} \\
\text { energy of viscous deformation, } \mathrm{E}_{\mathrm{v}} \cdot 10^{4}, \mathrm{~J} \\
\text { viscosity determined according to the Kelvin-Voigt } \\
\text { model, } \mathrm{N} \cdot \mathrm{s} \\
\text { viscosity determined according to the Maxwell model, } \\
\mathrm{N} \cdot \mathrm{s}\end{array}$} & 0.86 & 0.90 & 0.97 & 1.01 & 1.03 & 0.89 & 1.02 \\
\hline & 143 & 0.128 & 0.116 & 0.107 & 0.114 & 0.137 & \\
\hline & 1.082 & 1.096 & 1.111 & 1.134 & 1.122 & 1.103 & \\
\hline & 4.2 & 4.258 & 4.658 & 4.827 & 4.952 & 4.471 & \\
\hline & 6.615 & 6.702 & 6.452 & 6.513 & 6.268 & 6.559 & 6.382 \\
\hline & 6 & 6.37 & 7.05 & 7.42 & 7.65 & 6.59 & 7. \\
\hline & 478.5 & 510.1 & 525.6 & 530.5 & 614.1 & 518.2 & 658.9 \\
\hline The maximum wear at gas-abrasive influence, $\Delta \mathrm{V} \cdot 10^{3}, \mathrm{~cm}^{3}$ & 22.0 & 21.1 & 16.8 & 15.0 & 11.2 & 18.2 & 5.0 \\
\hline
\end{tabular}

composites are also caused by the formed threedimensional structure: when cross-linking is reduced, the energy of elastic deformation decreases whereas the energy of viscous deformation increases. The high values of the elastic deformation energy achieved with Epikure F-205 and CeTePox $1410 \mathrm{H}$ hardeners ensure increased wear resistance of epoxy composites under the conditions of intense gas-abrasive wear. With an increase in the proportion of inelastic deformations, the use of Ancamine hardeners increases deformation and strength at the time of tensile failure.

The influence of the ratio betwenn elastic and viscous characteristics of epoxy composites is even more reflected in their properties (Table 2) under additional heat treatment (to the main mode $20^{\circ} \mathrm{C} \times 24 \mathrm{~h}$ ) at various temperatures $\left(60-140^{\circ} \mathrm{C}\right)$. The nature of the destruction of composite samples upon compression after additional heat treatment (Fig. 2) corresponds to the changes in the energy of their deformation and its components (i.e. the energies of elastic and viscous deformation). When testing the samples after their heat treatment at $60^{\circ} \mathrm{C}$, a long plateau after the first threshold is observed which corresponds to plastic deformation practically without an increase in the resistance to deformation. A similar type of fracture under compression was noted when testing samples after heat treatment at $80-100^{\circ} \mathrm{C}$.

With an increase in the heat treatment temperature $\left(120^{\circ} \mathrm{C}\right)$, the first threshold is rapidly followed by an increase in the deformation resistance to the second threshold of final destruction of the composite, reflecting the loss of plastic deformation and the enhancement of brittleness. A further increase

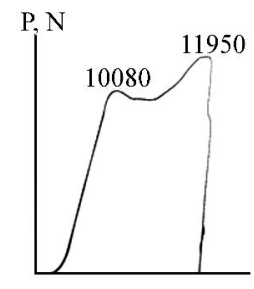

a

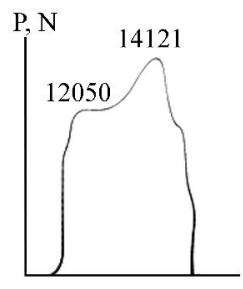

b

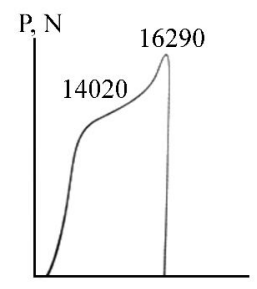

c

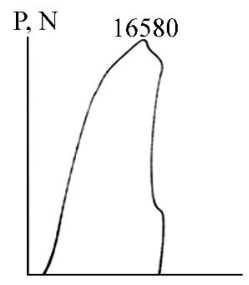

Fig. 2. Diagrams of compression of unfilled epoxy composites on the basis of ED-20 after their heat treatment on the modes: $\mathrm{a}-$ without heat treatment; b $-60^{\circ} \mathrm{C} \times 3 \mathrm{~h} ; \mathrm{c}-120^{\circ} \mathrm{C} \times 1 \mathrm{~h} ; \mathrm{d}-140^{\circ} \mathrm{C} \times 1 \mathrm{~h}$ 
in the heat treatment temperature $\left(140^{\circ} \mathrm{C}\right)$ is inexpedient because of the increased fracture in the process of composites after hardening, which leads to a decrease in the dynamic modulus of elasticity, deformation energy, and wear resistance of the composites. The optimum is the optimized (i.e. combined $80+100^{\circ} \mathrm{C}$ ) heat treatment conditions (Table 2, Fig. 3).

The analysis of the $\mathrm{X}$-ray diffraction patterns of samples of epoxy composites (Fig. 3) revealed the effect of heat treatment on the size of the cells formed by the interstitial chains of polymers of the mesh structure. The X-ray diffraction pattern of an epoxy polymer heat-treated at $100^{\circ} \mathrm{C}$ for 3 hours (Fig. 3, curve 1) manifests two diffusion maxima (as judged from the angular half-width) of different intensities with angular positions $(2 \mu \mathrm{m})$ of about $4.0^{\circ}$ and $17.6^{\circ}$. According to Bragg's equation, the average distance between two adjacent interstitial sites of the molecular chains of a polymer grid is $2.21 \mathrm{~nm}$ and $0.50 \mathrm{~nm}$, respectively, i.e. the mesh size of a polymer grid is $2.21-0.50 \mathrm{~nm}$. Heat treatment at $120^{\circ} \mathrm{C}$ (Fig. 3, curve 2) does not cause changes in the angular position $\left(2 \Theta_{\mathrm{m}}\right)$ of both diffraction maxima and the distance between two adjacent interstitial sites of molecular chains of the polymer grid. The heat treatment according to the optimized mode $\left(80+100^{\circ} \mathrm{C}\right)$ leads to densification of the polymer grid which is testified by the basic shift in the intensity of the amorphous halo in the diffractogram of this sample to the region of larger scattering angles: up to $2 \Theta_{\mathrm{m}}=18.2^{0}$ (Fig. 3, curve 3). At the same time,

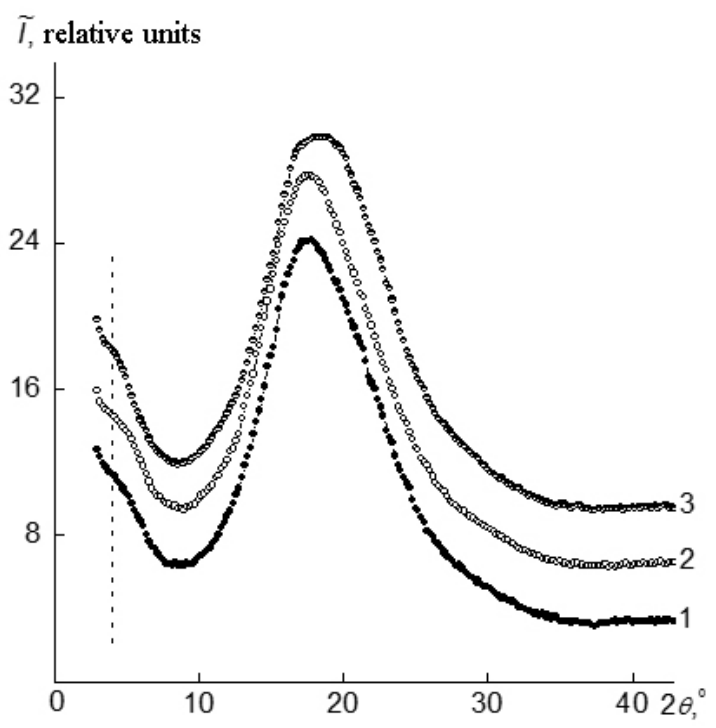

Fig. 3. Wide-angle X-ray diffractograms of the composites on the basis of ED-20 epoxy cured by polyethylene polyamine with a heat treatment during $3 \mathrm{~h}$ at different temperatures, ${ }^{0} \mathrm{C}$ : $1-100 ; 2-120 ; 3-80+100$ the distance between two adjacent interstitial sites of molecular chains of the polymer decreases to $0.49 \mathrm{~nm}$.

The analysis of the intensity profiles of smallangle X-ray scattering showed that epoxy composites are structurally homogeneous on the nanodimensional level, regardless of the heat treatment mode, since there is no contrast of electronic density in their volume.

An increase in the temperature of the heat treatment of epoxy polymers from 60 to $100^{\circ} \mathrm{C}$ is followed by an increase in the glass transition temperatures $\left(T_{g}\right)$, transition to highly elastic condition $\left(T_{e}\right)$, the modulus of high-elasticity $\left(E_{e}\right)$ which is due to a more complete participation of epoxide groups in the cross-linking reactions and an increase in the cross-linking density (a decrease in the sol fraction and the average molecular mass of interstitial chains (Table 2)).

With an increase in the heat treatment temperature of epoxy polymers from 100 to $120^{\circ} \mathrm{C}$ and especially to $140^{\circ} \mathrm{C}$, a slight decrease (at $120^{\circ} \mathrm{C}$ ) and then a more pronounced decrease in their thermomechanical characteristics are observed, the sol-fraction content and the average molecular mass of interstitial chains increase simbatically. Therefore, the effects of the heat treatment temperature of epoxy polymers in the vitreous (up to $100^{\circ} \mathrm{C}$ ) and highly elastic $\left(120 \pm 140^{\circ} \mathrm{C}\right)$ states on their thermomechanical properties are different.

Using the developed combined heat treatment of epoxy polymers at temperatures of the polymer in a vitreous state $\left(80^{\circ} \mathrm{C}\right)$ and close to the vitrification temperature $\left(100^{\circ} \mathrm{C}\right)$ promotes the formation of a more cross-linked structure providing enhanced thermomechanical properties.

\section{Conclusions}

The effects of industrial polyamines on the hardening process, the parameters of the threedimensional structure, the physical-mechanical and viscoelastic properties of epoxy compositions based on a mixture of dianic (ED-20) and aliphatic (DEG-1) epoxy resins have been determined. Taking into account the technological and operational properties of these resins, it is recommended to use Polyamine $\mathrm{B}$ for hardening.

The maximum temperature of the exothermic curing reaction of the studied epoxy compositions has been determined, depending on the polyamine hardener used. These values should be taken into account when compiling and adjusting the regimes of preparing the products for structural purposes.

Taking into account the established viscoelastic transition in epoxy composites, it is advisable to heat- 
treat them after their curing at $20^{\circ} \mathrm{C}$ in a vitreous state at the temperatures close to the glass transition temperature in order to achieve their optimal viscoelastic properties under dynamic loading.

The effects of the temperature of additional heat treatment $\left(60-140^{\circ} \mathrm{C}\right)$ on the change in thermomechanical properties and the nature of the destruction of epoxy composites have been shown. It was proposed to apply a combined $\left(80+100^{\circ} \mathrm{C}\right)$ heat treatment regime.

\section{REFERENCES}

1. Encyclopedia of polymer science and technology / H.F. Mark (ed.). - Wiley, 2004. - 3005 p.

2. Epoxy polymers: new materials and innovations / J.R. Pascault, J.J. Williams (eds.). - Wiley, 2010. - 367 p.

3. Gazoabrazyvne znoshuvannya epoksydnykh kompozytiv / Poloz O.Yu., Lipickij S.G., Kushhenko S.N., Semenets O.A., Ebich Yu.R. // Voprosy Khimii i Khimicheskoi Tekhnologii. 2012. - No. 1. - P.75-80.

4. Poloz O.Yu., Lipitskiy S. G., Kushchenko S.M. Znosostiyki epoksydni kompozyty konstruktsiynogo priznachennya // Khimichna Promislovist' Ukraini. - 2015. - Vol.5(130). - P.2527.

5. Jager M., Gotie K. Abrazivnyi iznos - nerazreshimaya problema? // Kompozitnyi Mir. - 2010. - Vol.2. - P.6-15.

6. Lee H.L., Neville K. Handbook of epoxy resins. McGraw-Hill Book Co., 1967. - 960 p.

7. Izuchenie protsessa otverzhdeniya svyazuyushchego na osnove bifunktsional'nogo epoksidnogo oligomera v smesi s tetrai poliglitsidilovymi modifikatorami razlichnymi metodami / Volkov A.S., Kryuchkov I.A., Kazakov S.I., Gorbunova I.Yu., Kerber M.L. // Plasticheskie Massy. - 2008. - Vol.10. - P.7-10.

8. Vyazkouprugie svoistva iznosostoykikh epoksidnykh kompozitov / Poloz A.Yu., Ebich Yu.R., Dolinskaya R.M., Mozgalev V.V. // Voprosy Khimii i Khimicheskoi Tekhnologii. - 2013. - No. 5. - P.72-77.

9. Osobennosti ekzotermicheskoi reaktsii otverzhdeniya iznosostoykikh epoksidnykh kompozitsii poliaminami / Poloz O.Yu., Lipickij S.G., Kushhenko S.N., Ebich Yu.R., Ivanova Ye.A. // Voprosy Khimii i Khimicheskoi Tekhnologii. 2013. - No. 6. - P.61-65.
10. Issledovanie vliyaniya polisul'fidnykh oligomerov v sostave kompozitsii na osnove oligoakrilatov na protsess strukturoobrazovaniya i svoistva materialov / Novakov I.A., Chalyh A.E., Nistratov A.V., Frolova V.I., Hasbiullin R.R., Klimov V.V. // Plasticheskie Massy. - 2011. - Vol.6. - P.18-22.

11. Treloar L.R. The physics of rubber elasticity. Third Edition. - Oxford: Clarendon Press, 2005. - 324 p.

12. Paramonov Yu.M., Artemov V.N., Klebanov M.S. K voprosu otsenki plotnosti sshivki epoksipolimerov po termomekhanicheskim dannym // Reaktsionnosposobnye oligomery, polimery i materialy na ikh osnove. -1976 . - Vol.3. - P.81-87.

13. Kratky O., Pilz I., Schmitz P.J. Absolute intensity measurement of small-angle $\mathrm{x}$-ray scattering by means of a standard sample // J. Colloid Interface Sci. - 1966. - Vol.21. P.24-34.

14. Kren'A.P., Rudnitskii V.A., Dejkun I.G. Opredelenie vyazkouprugikh parametrov rezin metodom dinamicheskogo indentirovaniya $\mathrm{s}$ ispol'zovaniem nelineinoi modeli deformirovaniya // Kauchuk i rezina. - 2004. - Vol.6. - P.1923.

15. Ward I.M. Mechanical properties of solid polymers. Third Edition. - Wiley, 2013. - 476 p.

Received 09.07.2018

\section{ВПЛИВ ПОЛІАМІНІВ НА ВЛАСТИВОСТ ЕПОКСИДНИХ КОМПОЗИТІВ}

\section{О.Ю. Полоз, М.Р. Прокопчук, Р.М. Долинська, Ю.Р. Ебіч}

Визначені в'язкопружні властивості композицій на основі епоксидної діанової смоли ЕД-20 в суміші з аліфатичною епоксидною смолою ДЕГ-1 в залежності від застосовуваного промислового поліамінного твердника, додаткового термооброблення (при температурах $60-140^{\circ} \mathrm{C}$ ). Показані відмінності термомеханічних, фізико-механічних властивостей, що виникають внаслідок змін співвідношення енергій пружного та в'язкого деформування. На співвідношення енергій пружного та в 'язкого деформування композицій в динамічному режимі напруження впливає сформована просторова структура епоксидної матриці. Показано вплив температури додаткової термообробки на зміну термомеханічних властивостей, характер руйнування епоксидних композицій $і$ запропоновано застосовувати комбінований $\left(80+100^{\circ} \mathrm{C}\right)$ режим термооброблення. Для досягнення оптимальних в 'язкопружних властивостей одержані епоксидні композиції після отверднення при $20^{\circ}$ С доцільно термооброблювати в склоподібному стані при температурах, близьких до температури склування, $і$ використовувати твердник Polyamine $B$.

Ключові слова: епоксидна смола, поліамінний твердник, зшита структура, в’язкопружні властивості, зносостійкість. 


\section{THE INFLUENCE OF POLYAMINES ON THE PROPERTIES OF EPOXY COMPOSITES}

A.Yu. Poloz a, N.R. Prokopchuk ${ }^{b}$, R.M. Dolinskaya ${ }^{b}$, Yu.R. Ebich ${ }^{c,}$ *

a LTD «New Technologies», Dnipro, Ukraine

${ }^{\mathrm{b}}$ Belarusian State Technological University, Minsk, Belarus

${ }^{c}$ Ukrainian State University of Chemical Technology, Dnipro, Ukraine

\section{*e-mail: vektor@imail.ru}

The viscoelastic properties of epoxy resin-based composites ED-20 in a mixture with aliphatic epoxy resin DEG-1 have been determined as functions of the applied industrial polyamine hardener and additional heat treatment (at the temperatures of $60-140^{\circ} \mathrm{C}$ ). The differences in the thermomechanical and physical-mechanical properties, and wear resistance of the composites have been stated resulted from the change in the ratio of the energies of elastic and viscous deformation. The ratio of the energies of elastic and viscous deformation of composites in a dynamic loading mode is influenced by the formed spatial cross-linked structure of the epoxy matrix. The effects of the temperature of additional heat treatment on the change in thermomechanical properties and the nature of the destruction of epoxy composites have been shown. It has been proposed to apply a combined heat treatment conditions $\left(80+100^{\circ} \mathrm{C}\right)$. To achieve optimum viscoelastic properties after hardening at $20^{\circ} \mathrm{C}$, it is expedient to heat-treat the obtained epoxy composites in a vitreous state at temperatures close to vitrification temperature and use a Polyamine $B$ hardener.

Keywords: epoxy resin; polyamine hardener; cross-linked structure; viscoelastic properties; wear resistance.

\section{REFERENCES}

1. Mark H.F., Encyclopedia of polymer science and technology. Wiley, 2004. 3005 p.

2. Pascault J.R., Williams J.J., Epoxy polymers: new materials and innovations. Wiley, 2010. $367 \mathrm{p}$.

3. Poloz O.Yu., Lipickij S.G., Kushhenko S.N., Semenets O.A., Ebich Yu.R. Gazoabrazyvne znoshuvannya epoksydnykh kompozytiv [Gas-abrasive wear of epoxy composites]. Voprosy Khimii i Khimicheskoi Tekhnologii, 2012, no. 1, pp. 75-80. (in Ukrainian).

4. Poloz O.Yu., Lipitskiy S.G., Kushchenko S.M. Znosostiiki epoksydni kompozyty konstruktsiinogo pryznachenn'ya [Wear-resistant epoxy composites for constructional purposes]. Khimichna Promislovist' Ukrainy, 2015, vol. 5(130), pp. 25-27. (in Ukrainian).

5. Jager M., Got'e K. Abrazivnyi iznos - nerazreshimaya problema? [Is abrasion wear an insoluble problem?]. Kompozitnyi Mir, 2010, vol. 2, pp. 6-15. (in Russian).

6. Lee H.L., Neville K., Handbook of epoxy resins. McGrawHill Book Co., 1967. 960 p.
7. Volkov A.S., Kryuchkov I.A., Kazakov S.I., Gorbunova I.Yu., Kerber M.L. Izuchenie protsessa otverzhdeniya svyazuyushchego na osnove bifunktsional'nogo epoksidnogo oligomera $\mathrm{v}$ smesi s tetra- i poliglitsidilovymi modifikatorami razlichnymi metodami [Study of the curing process of a binder based on a bifunctional epoxy oligomer in a mixture with tetraand polyglycidyl modifiers by various methods]. Plasticheskie Massy, 2008, vol. 10, pp. 7-10. (in Russian).

8. Poloz A.Yu., Ebich Yu.R., Dolinskaya R.M., Mozgalev V.V. Vyazkouprugie svoistva iznosostoykikh epoksidnykh kompozitov [Viscoelastic properties of wear-resistant epoxy composites]. Voprosy Khimii i Khimicheskoi Tekhnologii, 2013, no. 5, pp. 7277. (in Russian).

9. Poloz O.Yu., Lipitskii S.G., Kushhenko S.N., Ebich Yu.R., Ivanova Ye.A. Osobennosti ekzotermicheskoi reaktsii otverzhdeniya iznosostoykikh epoksidnykh kompozitsii poliaminami [Features of the exothermic reaction of curing wearresistant epoxy compositions with polyamines]. Voprosy Khimii $i$ Khimicheskoi Tekhnologii, 2013, no. 6, pp. 61-65. (in Russian).

10. Novakov I.A., Chalyh A.E., Nistratov A.V., Frolova V.I., Hasbiullin R.R., Klimov V.V. Issledovanie vliyaniya polisul'fidnykh oligomerov $\mathrm{v}$ sostave kompozitsii na osnove oligoakrilatov na protsess strukturoobrazovaniya i svoistva materialov [Investigation of the effect of polysulfide oligomers in the compositions based on polyacrylate on the process of structure formation and properties of materials]. Plasticheskie Massy, 2011, vol. 6, pp. 18-22. (in Russian).

11. Treloar L.R., The physics of rubber elasticity. Third Edition. Clarendon Press, Oxford, 2005. 324 p.

12. Paramonov Yu.M., Artemov V.N., Klebanov M.S. K voprosu otsenki plotnosti sshivki epoksipolimerov po termomekhanicheskim dannym [On the assessment of epoxy crosslinking density by thermomechanical data]. Reaktsionnosposobnye Oligomery, Polimery i Materialy na ikh Osnove, 1976, vol. 3, pp. 81-87. (in Russian).

13. Kratky O., Pilz I., Schmitz P.J. Absolute intensity measurement of small-angle X-ray scattering by means of a standard sample. Journal of Colloid and Interface Science, 1966, vol. 21, pp. 24-34.

14. Kren’ A.P., Rudnitskii V.A., Dejkun I.G. Opredelenie vyazkouprugikh parametrov rezin metodom dinamicheskogo indentirovaniya $\mathrm{s}$ ispol'zovaniem nelineinoi modeli deformirovaniya [Determination of parameters of viscoelastic rubber by the method of dynamic indentation using a nonlinear model of the deformation]. Kauchuk i Rezina, 2004, vol. 6, pp. 19-23. (in Russian).

15. Ward I.M., Mechanical properties of solid polymers. Third Edition. Wiley, 2013. 476 p. 